Mitsuru Emi • Naoto Keicho • Katsushi Tokunaga

Harumi Katsumata - Sachi Souma · Koichiro Nakata

Yoshio Taguchi • Nobuya Ohishi • Arata Azuma • Shoji Kudoh

\title{
Association of diffuse panbronchiolitis with microsatellite polymorphism of the human interleukin 8 (IL-8) gene
}

\begin{abstract}
Diffuse panbronchiolitis (DPB) is a distinctive chronic inflammatory lung disease predominantly found in Asian populations. Although its etiology is unknown, DPB is considered to be a multifactorial disease of whose susceptibility is determined by genetic predisposition unique to Asians. We and others have previously reported that the B*5401 allele of the human leukocyte antigen (HLA)-B gene or a closely linked gene in the HLA region on 6p21.3 is one of the major genetic factors in susceptibility to this disease. However, the association with $\mathrm{B} * 5401$ is not absolute and the contribution of other genetic or environmental factors should also be considered. Here, four candidate genes that are postulated to play a role in the pathophysiology of DPB, namely, RON-kinase, CYP3A4, motilin, and interleukin (IL)-8, were chosen, and association studies between microsatellite markers at these loci and DPB were conducted. We demonstrated the presence of a specific allele at the IL-8 locus was associated with the disease (c2 = 9.13; $P=0.0025$; corrected $P[P \mathrm{c}]<0.05)$. Although further studies are needed to examine whether neutrophil accumulation in the airways of patients with DPB is controlled by a
\end{abstract}

M. Emi $(\bowtie) \cdot$ H. Katsumata $\cdot$ S. Souma

Department of Molecular Biology, Institute of Gerontology, Nippon Medical School, 1-396 Kosugi-cho, Nakahara-ku, Kawasaki 211-8533, Japan

Tel. +81-44-733-5230; Fax +81-44-733-5192

e-mail:memi@nms.ac.jp

N. Keicho $\cdot$ N. Ohishi

Department of Respiratory medicine, University of Tokyo, Tokyo, Japan

K. Tokunaga

Department of Human Genetics, University of Tokyo, Tokyo, Japan

K. Nakata

Toranomon Hospital, Tokyo, Japan

K. Taguchi

Tenri Hospital, Nara, Japan

A. Azuma $\cdot$ S. Kudoh

Fourth Department of Internal Medicine, Nippon Medical School,

Tokyo, Japan possible genetic variation of IL-8 or other chemokine genes located in the region $4 \mathrm{q} 12$-q13, our data suggest that genes other than those of the HLA system may also contribute to a genetic predisposition to DPB.

Key words Diffuse panbronchiolitis · Interleukin $8 \cdot$ Allelic association $\cdot$ Microsatellite

\section{Introduction}

Diffuse panbronchiolitis (DPB) is a distinctive chronic inflammatory airway disease of unknown etiology (Homma et al. 1983; Corne 1996) that affects both the upper and lower respiratory tract. Patients present with a history of chronic cough, sputum production, and dyspnea on exertion and almost always give a long history of sinusitis. Since DPB was first described in Japan, many cases have been reported in East Asians, including Chinese and Koreans (Kim et al. 1992). Sporadic familial cases have also been noted (Suzuki et al. 1981). In non-Asian populations, however, only a limited number of patients are known (Fitzgerald et al. 1996).

Pathologically, the disease is characterized by inflammatory lesions with infiltration of lymphoid cells and foamy macrophages around respiratory bronchioles. In the bronchoalveolar lavage fluid of pacients with DPB, accumulation of neutrophils in parallel with increased neutrophil chemotactic activity has been well described (Ichikawa et al. 1990; Kadota et al. 1993). Recently, the prognosis of the disease has been improved dramatically by low-dose erythromycin therapy (Kudoh et al. 1998), the effect of which is attributed to its anti-inflammatory action (Kadota et al. 1993; Koyama and Gaddes. 1997).

Previously, we and others reported that the human leukocyte (HLA)-B*5401 allele encoding the B54 class I antigen unique to East Asians was strongly associated with the disease (Sugiyama et al. 1990; Keicho et al. 1998), whereas HLA-B44 showed negative association with the disease. Although these results suggest that DPB is influenced by 
genetic factors mapped within the HLA region on the sixth chromosome $6 \mathrm{p} 21.3$, the contribution of other genetic or environmental factors should also be taken into account, as the B*5401 and its related alleles were found in only a half of the patients.

In the present study, we investigated four candidate genes whose products are implicated in the airway inflammation of DPB or the non-antimicrobial effects of erythromycin. As suggested above, chronic inflammation in the airway or the action of erythromycin on the host may be a key to elucidate the disease mechanism of DPB. We selected the following four candidate genes for these reasons. (1) Interleukin (IL)-8, as it is a major component of neutrophil chemotactic activity in the airway. Elevation of IL-8 concentrations in the airways of patients with DPB has been reported (Sakito et al. 1996). (2) CYP3A4, a member of the cytochrome $\mathrm{P} 450$ family, is inducible by erythromycin and its catalytic activity plays a central role in the oxidative metabolism of both endogenous and exogenous compounds in humans (Hashimoto et al. 1993). (3) RON-kinase, a receptor for macrophage stimulating protein, is expressed on the apical surface of ciliated airway epithelium and its major role in the airway appears to be in activating the mucociliary transport system (Sakamoto et al. 1997). In an earlier report, impaired mucociliary function was demonstrated in two patients with DPB (Amitani et al. 1988). (4) Motilin is known as an enteric hormone, although expression of its gene has been demonstrated in bronchial as well as in intestinal cells (Gasparini et al. 1994). Interestingly, erythromycin has been shown to occupy the motilin receptor and mimic its action (Kondo et al. 1988).

\section{Subjects and methods}

Subjects

Eighty-five Japanese patients with DPB at Toranomon Hospital, Tenri Hospital or Nippon Medical School Hospital fulfilled the diagnostic criteria described elsewhere (Keicho et al. 1998) and participated in this study. The normal controls here were 88 Japanese volunteers.

Analysis of microsatellite markers at the candidate loci

Genomic DNA was extracted from whole blood samples (Wang et al. 1994). Microsatellite markers tested were determined as follows; for IL-8, the marker D4S2641, located on the IL-8-harboring YAC clones 752d11/902a10, was used to represent this locus; for CYP3A4, the marker D7S2432, located on the CYP3A4-harboring YAC clones $783 \mathrm{~b} 4 / 808 \mathrm{f3}$, was used; for RON kinase, the marker D3S1448, located on the YAC clone harboring MST1R encoding RON kinase was used; for motilin, the marker D6S248, located on the motilin-harboring YAC clones 788e2/844d9, was used.

Microsatellites were amplified by PCR with ${ }^{32} \mathrm{P}$-labeled primers, according to the published amplification conditions (http://gdbwww.gdb.org/). The alleles were separated on a 0.2 -mm-thick, $6 \%$ denaturing polyacrylamide gel and dried by heat gel dryer, and radiolabeled bands were visualized by autoradiography. The alleles (A1-A8) number reported in Results represents the relative size of the alleles.

\section{Statistical analysis}

Disease association was assessed by the $\chi^{2}$ test. Corrected $\mathrm{P}$ values $(P \mathrm{c})$, (i. e., $P$ values multiplied by the number of comparisons made) were calculated. $P$ c values less than 0.05 were considered significant.

\section{Results}

Microsatellite markers at the four candidate genes encoding motilin, CYP3A4, RON-kinase, and IL-8 were analyzed. The allele frequencies of each marker were compared between the patients and control subjects.

As shown in Tables 1 to 4 , microsatellites at the CYP3A4, RON-kinase, motilin, and IL-8 loci, respectivly, exhibited 8, 7, 9, and 11 alleles, respectively in the Japanese population examined. Although polymorphisms at the CYP3A4, RON-kinase, and motilin loci did not show significant associations with the occurence of DPB, a definite

Table 1 Allele frequencies of a polymorphism at the CYP3A4 locus in DPB

\begin{tabular}{ccccc}
$\begin{array}{l}\text { D7S2432 } \\
\text { alleles }\end{array}$ & $\begin{array}{c}\text { Allele } \\
\text { size } \\
(\mathrm{bp})\end{array}$ & $\begin{array}{c}\text { Chromosome } \\
\text { no. in DPB } \\
(n=164)\end{array}$ & $\begin{array}{c}\text { Chromosome } \\
\text { no. in controls } \\
(n=176)\end{array}$ & $\begin{array}{l}\text { Statistical } \\
\text { significance }\end{array}$ \\
\hline A1 & 133 & 1 & 1 & NS \\
A2 & 131 & 3 & 3 & NS \\
A3 & 129 & 5 & 9 & NS \\
A4 & 127 & 104 & 101 & NS \\
A5 & 125 & 28 & 37 & NS \\
A6 & 123 & 20 & 19 & NS \\
A7 & 121 & 2 & 4 & NS \\
A8 & 119 & 0 & 1 & \\
\hline
\end{tabular}

DPB, Diffuse panbronchiolitis; NS, not significant

Table 2 Allele frequencies of a polymorphism at the RON-kinase locus in DPB

\begin{tabular}{ccccc}
\hline $\begin{array}{l}\text { D3S1448 } \\
\text { alleles }\end{array}$ & $\begin{array}{c}\text { Allele } \\
\text { size } \\
(\mathrm{bp})\end{array}$ & $\begin{array}{c}\text { Chromosome } \\
\text { no. in DPB } \\
(n=85)\end{array}$ & $\begin{array}{c}\text { Chromosome } \\
\text { in controls } \\
(n=172)\end{array}$ & $\begin{array}{l}\text { Statistical } \\
\text { significance }\end{array}$ \\
\hline A1 & 204 & 2 & 3 & NS \\
A2 & 202 & 5 & 6 & NS \\
A3 & 200 & 13 & 11 & NS \\
A4 & 198 & 21 & 20 & NS \\
A5 & 196 & 99 & 121 & NS \\
A6 & 194 & 18 & 12 & NS \\
A7 & 192 & 11 & 3 & NS \\
\hline
\end{tabular}


Table 3 Allele frequencies of a polymorphism at the motilin locus in DPB

\begin{tabular}{ccccc}
\hline $\begin{array}{l}\text { D6S248 } \\
\text { alleles }\end{array}$ & $\begin{array}{c}\text { Allele } \\
\text { size } \\
(\mathrm{bp})\end{array}$ & $\begin{array}{c}\text { Chromosome } \\
\text { no. in DPB } \\
(n=164)\end{array}$ & $\begin{array}{c}\text { Chromosome } \\
\text { no. in controls } \\
(n=176)\end{array}$ & $\begin{array}{l}\text { Statistical } \\
\text { significance }\end{array}$ \\
\hline A1 & 287 & 0 & 1 & NS \\
A2 & 285 & 55 & 44 & NS \\
A3 & 283 & 21 & 15 & NS \\
A4 & 281 & 24 & 31 & NS \\
A5 & 279 & 2 & 9 & NS \\
A6 & 277 & 15 & 15 & NS \\
A7 & 275 & 1 & 3 & NS \\
A8 & 273 & 39 & 48 & NS \\
A9 & 271 & 5 & 10 & NS \\
\hline
\end{tabular}

Table 4 Allele frequencies of a polymorphism at the IL-8 locus in DPB

\begin{tabular}{ccccc}
\hline $\begin{array}{l}\text { D4S2641 } \\
\text { alleles }\end{array}$ & $\begin{array}{c}\text { Allele } \\
\text { size } \\
(\mathrm{bp})\end{array}$ & $\begin{array}{c}\text { Chromosome } \\
\text { no. in DPB } \\
(n=144)\end{array}$ & $\begin{array}{c}\text { Chromosome } \\
\text { no. in controls } \\
(n=172)\end{array}$ & $\begin{array}{l}\text { Statistical } \\
\text { significance }\end{array}$ \\
\hline A1 & 293 & 2 & 0 & NS \\
A2 & 289 & 89 & 77 & $P$ c $<0.05^{*}$ \\
A3 & 285 & 16 & 20 & NS \\
A4 & 281 & 0 & 1 & NS \\
A5 & 277 & 25 & 26 & NS \\
A6 & 273 & 3 & 8 & NS \\
A7 & 269 & 3 & 15 & NS \\
A8 & 265 & 6 & 16 & NS \\
A9 & 261 & 0 & 7 & NS \\
A10 & 257 & 0 & 1 & NS \\
A11 & 253 & 0 & 1 & NS
\end{tabular}

* The frequency of the A2 allele was significantly increased in DPB patients

IL-8, Interleukin 8; $P$ c, corrected $P$ value; see text for explanation

association between the microsatellite at the IL- 8 locus and the disease was demonstrated (Table 4). Allele 2 of this polymorphism was present in $62 \%$ of the DPB patient group and in $45 \%$ of the control group $\left(\chi^{2}=9.13 ; P=0.0025\right.$, $P(\mathrm{c}<0.05)$.

\section{Discussion}

To examine genes for susceptibility to DPB, we analyzed four candidate genes. Of these examined candidates, allele 2 of the microsatellite polymorphism at the IL-8 locus showed a positive association with the disease. As the microsatellite and the IL8 locus are located on the same YAC clone, allele 2 of the polymorphism may be in linkage disequilibrium with etiological variation of the IL-8 gene, and such a variation of the IL- 8 gene could be involved in susceptibility to the disease. On the other hand, the contribution of the other genes tested cannot be excluded, because specific alleles in the adjacent markers may not be in strong linkage disequilibrium with allelic variants, and they thus escape detection by the disease association method.
It is not known whether there is a possible variant of IL8 gene affecting its own activity or expression. So far, no polymorphism has been reported within the promoter or coding sequence of human IL-8 gene. However, neutrophil accumulation in the airway lumen is one of the most characteristic findings in DPB (Homma et al. 1983). Neutrophil chemotactic activity including IL-8 is increased in the airway of patients with DPB and suppressed after low-dose erythromycin therapy (Kadota et al. 1993; Sakito et al. 1996). Therefore, when we consider genetic predisposition in patients with DPB, a gene causing excessive neutrophil accumulation in the airway could be a candidate for a disease susceptibility gene.

In a narrow region of $4 \mathrm{q} 12-13$, i.e., less than $2 \mathrm{Mb}$ on the long arm of chromosome 4 , a cluster of genes encoding the chemokines including IL-8, have been mapped (Tunnacliffe et al. 1992; Modi et al. 1998). The members of this cluster include GRO1, GRO2 (also known as MIP-2a), GRO3, and SCYB5, encoding ENA-78. Interestingly, their gene products also primarily mediate the migration of neutrophils. It is likely that these genes are derived through tandem gene duplication from a common ancestral gene, presumably located on human chromosome 4 (Modi et al. 1998). Therefore, one of these chemokines located in the narrow region of 4q12-13 may well be in linkage disequilibrium with the relevant allele of the polymorphism associated with DPB. Such a gene may turn out to be responsible for the regulation of neutrophil accumulation in DPB. In future studies, we should further examine 4q12-q13 as well as HLA regions at 6 p21.3 to identify unknown DPB susceptibility genes.

Acknowledgments This work was supported by research grants for Surveys and Research on Specific Diseases from the Ministry of Health and Welfare of Japan, in 1997 and 1998.

\section{References}

Amitani R, Tanaka E, Kuze F (1988) A study of ultrastructure and motility of tracheo-bronchial cilia in patients with diffuse panbronchiolitis. Jpn J Chest Dis 47: 483-490

Corne J (1996) Diffuse panbronchiolitis: A new Japanese export? Lancet 348: 1465-1466

Fitzgerald JE, King Jr TE, Lynch DA, Tuder RM, Schwarz MI (1996) Diffuse panbronchiolitis in the United States. Am J Respir Crit Care Med 154: 497-503

Gasparini P, Grifa A, Savasta S, Merlo I, Bisceglia L, Totaro A, Zelante L (1994) The motilin gene: Subregional localisation, tissue expression, DNA polymorphisms and exclusion as a candidate gene for the HLAassociated immotile cilia syndrome. Hum Genet 94: 671-674

Hashimoto H, Toide K, Kitamura R, Fujita M, Tagawa S, Itoh S, Kamataki T (1993) Gene structure of CYP3A4, an adult-specific form of cytochrome P450 in human livers, and its transcriptional control. Eur J Biochem 218: 585-595

Homma H, Yamanaka A, Tanimoto S, Tamura M, Chizimatsu Y, Kira S, Izumi T (1983) Diffuse panbronchiolitis: A disease of the transitional zone of the lung. Chest 83: 63-69

Ichikawa Y, Koga H, Tanaka M, Nakamura M, Tokunaga N, Kaji M (1990) Neutrophilia in bronchoalveolar lavage fluid of diffuse panbronchiolitis. Chest 98: 917-923

Kadota J, Sakito O, Kohno S, Sawa H, Mukae H, Oda H, Kawakami K, Fukushima K, Hiratani K, Hara K (1993) A mechanism of erythromycin treatment in patients with diffuse panbronchiolitis. Am Rev Respir Dis 147: 153-159 
Keicho N, Tokunaga K, Nakata K, Taguchi Y, Azuma A, Bannai M, Emi M, Ohishi N, Yazaki Y, Kudoh S (1998) Contribution of HLA genes to genetic predisposition in diffuse panbronchiolitis. Am J Respir Crit Care Med 158: 846-850

Kim YW, Han SK, Shim YS,Kim KY, Han YC, Seo JW, Im JG (1992) The first report of diffuse panbronchiolitis in Korea: Five case reports. Intern Med 31: 695-701

Kondo Y, Torii K, Itoh Z, Omura S (1988) Erythromycin and its derivatives with motilin-like biological activities inhibit the specific binding of 125I-motilin to duodenal muscle. Biochem Biophys Res Commun 150: 877-882

Koyama H, Geddes DM (1997) Erythromycin and diffuse panbronchiolitis. Thorax 52: 915-918

Kudoh S, Azuma A, Yamamoto M, Izumi T, Ando M (1998) Improvement of survival in patients with diffuse panbronchiolitis treated with low-dose erythromycin. Am J Respir Crit Care Med 157:1829-1832

Modi WS, Chen Z-Q (1998) Localization of the human CXC chemokine subfamily on the long arm of chromosome 4 using radiation hybrids. Genomics 47: 136-139

Sakamoto O, Iwama A, Amitani R, Takahara T, Yamaguchi N,
Yamamoto T, Masuyama K, Yamanaka T, Ando M, Suda T (1997) Role of macrophage-stimulating protein and its receptor, RON tyrosine kinase, in ciliary motility. J Clin Invest 99: 701-709

Sakito O, Kadota J, Kohno S, Abe K, Shirai R, Hara K (1996) Interleukin $1 \mathrm{~b}$, tumor necrosis factor alpha, and interleukin 8 in bronchoalveolar lavage fluid of patients with diffuse panbronchiolitis: A potential mechanism of macrolide therapy. Respiration 63: 42-48

Sugiyama Y, Kudoh S, Maeda H, Suzaki H, Takaku F (1990) Analysis of HLA antigens in patients with diffuse panbronchiolitis. Am Rev Respir Dis 141: 1459-1462

Suzuki M, Usui K, Tamura N, Araki T, Chijimatsu Y, Washizaki M, Inatomi K, Homma (1981) Familial cases of diffuse panbronchiolitis. Jpn J Thorac Dis 19: 645-651

Tunnacliffe A, Majumdar S, Yan B, Poncz M (1992) Genes for bthromboglobulin and platelet factor 4 are closely linked and form part of a cluster of related genes on chromosome 4. Blood 79: 2896-2900

Wang L, Hirayasu K, Ishizawa M, Kobayashi Y (1994) Purification of genomic DNA from human whole blood by isopropanol-fractionation with concentrated NaI and SDS. Nucleic Acids Res 22: 1774-1775 